\title{
非經口的二注入七儿肝臟細胞成分，血液
}

\section{Aceton 體量二及ボス影響}

\section{第三包報告 肝臟乳劑中ノ血液 Aceton 體量 二影響スル物質ノ性狀站二作用}

東京帝國大學傳染病研究所附屬醫院(主任 宮川数授)

$$
\text { 醫學士柴田秀夫 }
$$

\begin{tabular}{|c|c|}
\hline 目 次 & 場合 \\
\hline 第一章 緒 言 & 第四章 䏦臓乳劑中，血液 Aceton 體二影響 \\
\hline 第二章 植物神經毒卜血液 Aceton 體量卜， & スル物質ノ物理化學的性狀 \\
\hline 關係 & 第一項 純酒精 ヨ以テスル試驗 \\
\hline 第一項 Aderenalin 注入ノ場合 & 第二項 Aether ヨ以テスル試驗 \\
\hline 第二項 Atropin 注入ノ場合 & 第三項 純酒精二不溶部分 $ヨ$ 以テスル試驗 \\
\hline 第三項 Pilocarpin 注入ノ場合 & 第四項 硫酸「アムモン」ヨ以テスル試驗 \\
\hline 第三章 血液 Aceton 體量 $コ$ 見タル訮墭乳 & 第五項 吸著試驗 \\
\hline 乮作用卜植物神經毒作用卜 >關係 & 第六項 透析試驗 \\
\hline $\begin{array}{c}\text { 第一項 Adrenalin =因ル Acetonaemie } \\
\text { =對スル訮臟乳劑人影響 }\end{array}$ & $\begin{array}{l}\text { 第七項 兏化試驗 } \\
\text { 第入項 加熱試驗 }\end{array}$ \\
\hline 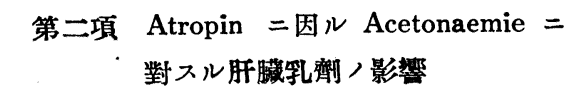 & $\begin{array}{l}\text { 第五章 } \\
\text { 總括及ビ考按 } \\
\text { 第章 }\end{array}$ \\
\hline 第三項 肝脿乳劑及ビ Pilocarpin 注入 & 主要 \\
\hline
\end{tabular}

\section{第一童 績 言}

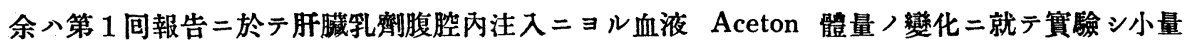
(體重「プロキロ」0.05gr.)注入ニョリテ $\beta$-Oxybutter 酸ノ著明ノ剒加 證明シス大量(體重「プロ

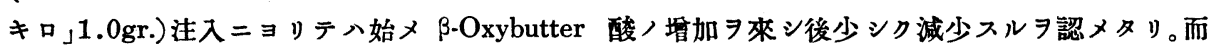
シテッ,間 Aceton 及ビ Acet-醋酸八殆ンド一定/變化习認メ得ザリキ。次イデ第 2 回報告二於 テ八諸種脂肪酸ノ注入 $=ョ$ テー定度ノ血液 Aceton 體量ノ增加 7 招來スル 量注入が能》Butter 酸筋肉內注入 $=ヨ ル$ Acetonaemie $ヨ$ 抑制スル作用アルヨ知レリ。於立血

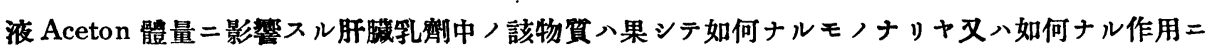
ヨルモノナリヤ.ソノ一端ヨ知ラント憼次ノ賽驗习試ミタリ。

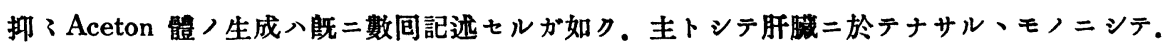

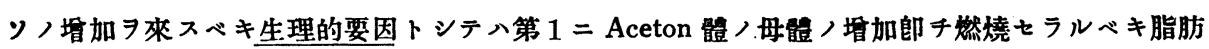

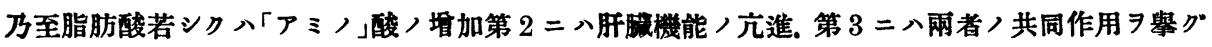


ベク．何レノ場合卜踓モ生理的二血中二增量シタルAceton 體ハ速カ二酸化分解セラレテ終末 産物卜化シ長時間二互リテ Aecton 體ノ、、體內二停マルコトナカルベシ。

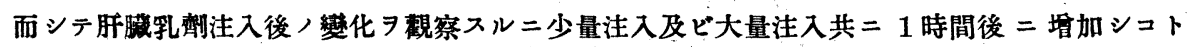

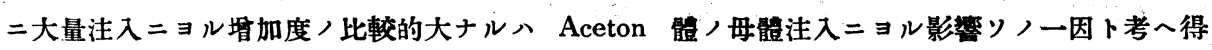

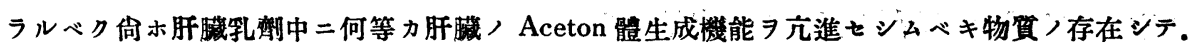
雨者相俟ツテ血液 Aceton 體 堵加 3 來スナラント八第 1 回報告二於テ推論セル所ナリ。然ルニ 大量注入 $ニ ョ リ テ 4$ 時間後二減少スルハカ、ル物筫ノ吸收セラレテ肝臟ヨ剌载スル事餘リ二大 ニ過ギ却ッテソノAceton 體生成機能ノ減退ヨ來セルモノト考フルヨ穻當ト信ズト述ベタリ。

然ラバカ、ル物質八如何ナル性狀ヨ有スルモノナリヤ. 又如何ニシテ肝臹习剌戟スルモノナリ

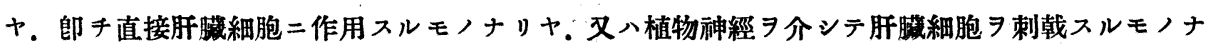
リヤ. 聊力實驗 所見二就キテソノ所以 $ᄏ$ 明カニセントス。

\section{第二章 植物神經毒卜血液 Aceton 错量トJ關係}

神經系統卜Aceton 體排出卜/關係二就テハ遠ク Lustig 八家鬼及犬二於テPlexus

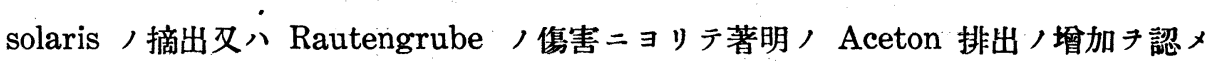
Peiper ハ15匹ノ家鬼二就キテ Plexussolaris ノ摘出き行七極僅微ノAceton 排出 認メタリ。省ホ精神的影響二關シテハ Marro 八臨林的二驚愕ニヨリテ著明ノAcetonaemie チオコスコトチ證明シ又. 犬キシテ 8 時間ノ間甚シキ深所テ俯橄セシメテ警 愕セシメ著明 Aceton 排出證明セリ。又 Waldvogel 八Koitus ニョル性的興奮 ニョルAceton 排出/如何テ檢シ. Koitus /行ハレタル12 時間中二ハ排出ノ增加 ナキモ次ノ 12 時間二於テ殆ンド正常ノ 3 倍二達スル排出アルチ見タリ。斯クノ如ク Aceton 體ノ排出八精神的若シク八神經的影響ノ少ナカラザルキ知ル。近時溝口氏八 犬二連日比較的大量, Adrenalin フ注入スル時ハ尿中 Aceton 體ノ著明ノ增加き來 スコトキ實驗シ 第 1 日. 第 2 日二最モ著明ニシテ後次第二減少スルコトチ報告セ !. Hirschhorn u. Pollak モ亦 Adrenalin ニョリ Acetonaemie キ起スコトチ實驗 的二登明シ. S. Seelig 八臨林的二肝臟病者及ビ非肝䁍病者二Adrenalin キ注射シ極 子 1 時間乃至 2 時間ニシテ血液 Aceton 體コトニ $\beta$-Oxybutter 酸ノ增加テ證明セ リ。郎チ Adrenalin ニョリテ血液 Aceton 體ノ增加スルコト八確實ナルガ如ク・一 般ニ之八 Adrenalin ニヨル肝臟 Glykogen ノ消失ト密接ナル關係アルガ如ク信ゼラ ル。之二就キテ F. Stroebe ノ如キハ肝㵴 Glykogen ガ早ク消失スレバ・ソレ丈ケ 早ク血液 Aceton 體が增加スルト篝シ。Adrenalinが植物神經キ介シテ䀒矌 Glykogen ノ減少乃至消失テ促シテ以テ Acetonaemie ヨオコスト推論セり。

余ハ先ヅ植物神經毒タル Adrenalin, Atropin 及 Pilocarpin キ家鬼ノ皮下二注入 
テ血液 Aceton 體量二及ボス影製キ检セリ。

\section{第一項 Adrenalin 注入ノ場合}

Adrenalin 1000 倍溶液き用七體重「プロキロ」0.1一0.3mgr. . . 皮下二注入シ 15 分 30 分. 1 時間. 2 時間ト探血シテ定量セリ。

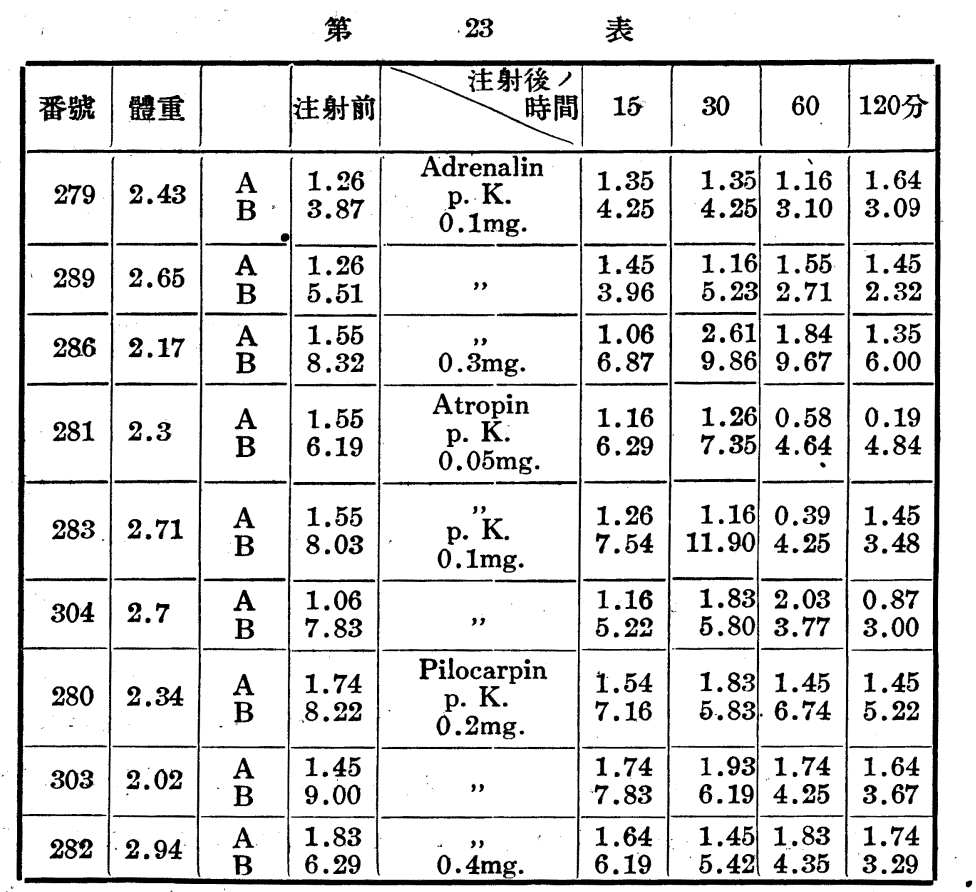

第 42 圖

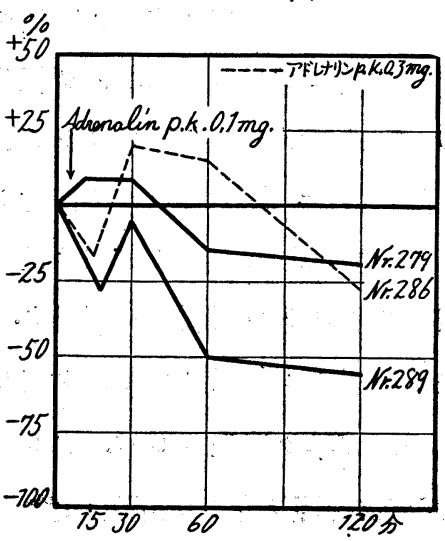

第 286 號ハ $0.3 \mathrm{mgr}$. キ注入七ルニ 15 分後一 旦低下七ルモ 30 分後二ハ $\beta$-Oxybutter 酸八 著明二增加シ 1 時間目二モ佾木上昇, 狀態二 アリ。2 時間目二八正常值二恢復セリ。「プロ キロ」0.1mgr. キ注入七ル第 279.280號八何 レモ 30 分後二於テ相當ノ增加 7 呈シ 1 時間 目二ハ減少セリ。而ジテコノ間 Aceton ハ大 體變化ナキモ $0.3 \mathrm{mgr}$. 注入ノトキハ 30 分後 二著シキ增加キ呈セリ。郎チ Adrenalin 注 入ニヨリテ血液 Aceton 體ハ增加テ來スモ， ト考へラル。 


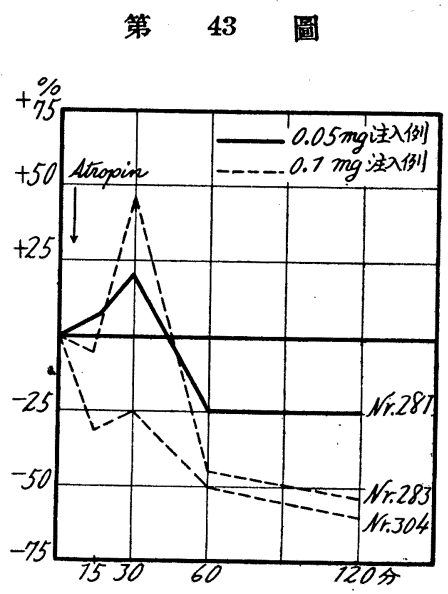

1 回ノ探血ニョリテ像メ標準ノAceton 體 量き定量セル家鬼二約 1 時間後 Atropin ₹ 體重「プロキロ」0.05一0.1mgr. 注入シテ 15 分. 30 分. 1 時間. 2 時間卜採血シテAceton キ定量セリ。然ル時八第 23 表二於ケルガ如 ク $0.05 \mathrm{mgr}$. キ注入 セル第 281 號二於テハ $\beta$-Oxybutter 酸八 15 分. 30 分卜漸次上昇 三 1 時間後漸ク減少セリ。然ル二0.1mgr. 尹注 入セル第 283 及ビ 304 號二於テハ 15 分後二 八增加スルコトナク. 30 分後二於テ著明二增 加シコトニ第 283 號二於テ甚シ。何レモ 1 時 間後ハ正常ニ復セリ。Aceton ハ殆ンド變化ナシ。

郎チ Atropin 注入ニヨリテモ 30 分後二於テ血液 Aceton 體ハ增加スルモ, 、如 シ。

\section{第三項 Pilocarpin 注入，場合}

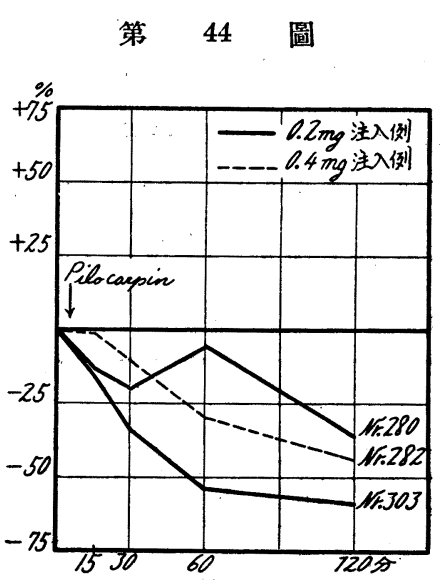

型ノ如ク標準值キ決定セル家鬼二約 1 時間後 Pilocarpin チ體重「プロキロ」0.2一0.4mgr. 注 入シ次イデ 15 分. 30 分. 1 時間. 2 時間卜採 血シテソノ影響キ检林。

$0.4 \mathrm{mgr}$. F注入七ル第 282 號二就キテ見ル 二何等正常ノ場合ト異ル所ナシ。次イデ 0.2 mgr. F注入七ル第 280 號二於テハ 1 時間後二 幾分增加セルガ如キモ同ジク $0.2 \mathrm{mgr}$. 注入七 ル第 303 號ニテハ何等ノ變化 モモ見ズ。大體.

Pilocarpin 注入二ヨリデ血液 Aceton 體八 著明ナル增加若シクハ減少チ來サジルモノト思

惟セラル。

本章摘要。交感神經毒タル Adrenalin ハ「プロキロ」0.1mgr. 注入ニヨリテ 30 分 後二著明ノ血液 Aceton 體コトニ $\beta$-Oxybutter 酸ノ增加チ來シ. 又副交感神經毒タ ルAtropin ニョリテ自律神經ノ本衡き破リテ Sympatikotonie ノ狀態トスル時ハ之 亦甚シク著明ニハ非ザルモ血液 Aceton 體ノ增加フ證明セラル。郎チ何等カ交感神經 
ノ㗨張ガ血液 Aceton ノ增加ト重要ナル關係ニアルモノ、如ク.思考セラル。而シテ Pilocarpin ニョリテ人工的ニ Vagotonie 狀態ニスルモ血液Aceton 體ニハ著シキ變 化き認メ得ザリキ。

\section{第三章 血液 Aceton 體量ヨリ㫕タル肝咸乳劑ノ 作用ト植物神經毒作用トノ關係}

前章ニ於テハ植物神經毒タル Adrenalin 及ビ Atropin 八血液 Aceton 體ノ增加

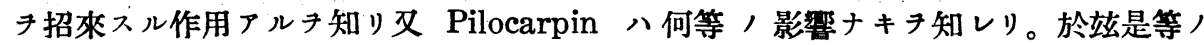
作用二對シ肝臟細胞成分注入ガ如何ニ影響スルカチ見ントス。

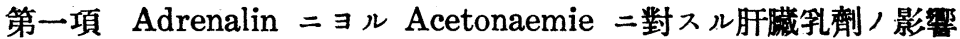

第 1 回及ビ第 2 回報告二於テ明ナルガ如ク肝贜乳劑. 大量キ腹腔內二注入スル時ハ 注入後大體 4 時間目二血液 Aceton 體量キ減少シ刃ハButter 酸注入ニヨル Aceto-

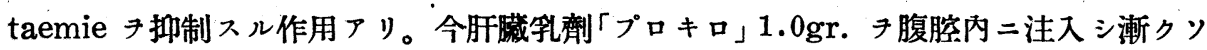
, Aceton 體生成抑制作用ノ表レントスル頃郎チ注入後約 3 時間牛ニシテ Adrenalin $0.1 \mathrm{mgr}$. 乃至 $0.3 \mathrm{mgr}$. 注入シ. 然ル後約 30 分ニシテ探血シテ Aceton 體量キ定量 セり。

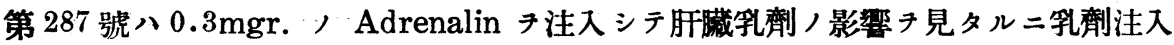
後 4 時間目ニシテ著明ノ增加キ來セり郎チコノ例ニ於テハ Adrenalin ニョル Acetonaemie 二對シテ䀒藏乳劑/抑制作用ア認メラレズ。然ルニ同ジク 0.3mgr. Adrenalin

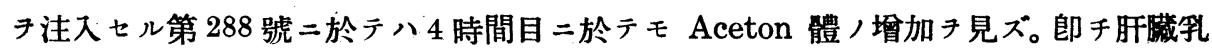

\begin{tabular}{|c|c|c|c|c|c|c|c|c|c|}
\hline 番號 & 體重 & & 注射前 & 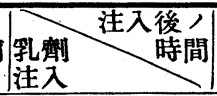 & 1 & 2 & 3 & $3_{2}^{1}$ & 4 \\
\hline 287 & 2.34 & $\begin{array}{l}\mathbf{A} \\
\mathbf{B}\end{array}$ & $\begin{array}{l}0.97 \\
5.32\end{array}$ & 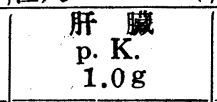 & $\begin{array}{l}0.97 \\
9.19\end{array}$ & $\begin{array}{l}0.77 \\
4.84\end{array}$ & \begin{tabular}{|l|}
0.68 \\
2.22
\end{tabular} & $\begin{array}{l}\text { Adrenal. } \\
\text { p. K. } \\
0.3 \mathrm{mg} .\end{array}$ & $\begin{array}{l}0.87 \\
4.16\end{array}$ \\
\hline 288 & 2.71 & $\begin{array}{l}\text { A } \\
\text { B }\end{array}$ & $\begin{array}{l}1.16 \\
6.29 \\
\end{array}$ & $"$ & $\begin{array}{l}1.16 \\
6.67\end{array}$ & & $\begin{array}{l}0.87 \\
3.67 \\
\end{array}$ & $"$ & $\begin{array}{l}1.16 \\
2.22 \\
\end{array}$ \\
\hline 296 & 2.7 & $\begin{array}{l}\mathbf{A} \\
\mathbf{B} \\
\end{array}$ & $\begin{array}{r}1.55 \\
.5 .90 \\
\end{array}$ & $"$ & $\begin{array}{l}1.74 \\
6.67 \\
\end{array}$ & $\begin{array}{l}1.55 \\
4.93 \\
\end{array}$ & \begin{tabular}{|l}
1.93 \\
4.16 \\
\end{tabular} & $0 . \ddot{m g}$ & $\begin{array}{r}1.74 \\
3.87 \\
\end{array}$ \\
\hline 297 & 2.9 & $\begin{array}{l}\text { A } \\
\text { B }\end{array}$ & \begin{tabular}{|l|}
1.74 \\
8.12 \\
\end{tabular} & " & $\begin{array}{l}1.93 \\
9.09\end{array}$ & \begin{tabular}{|l|}
1.55 \\
5.71 \\
\end{tabular} & $\begin{array}{l}1.84 \\
4.93 \\
\end{array}$ & $"$ & $\begin{array}{l}1.74 \\
4.74 \\
\end{array}$ \\
\hline 291 & 2.66 & $\begin{array}{l}\mathbf{A} \\
\mathbf{B}\end{array}$ & $\begin{array}{l}1.45 \\
8.12\end{array}$ & " & $\begin{array}{l}1.73 \\
8.12\end{array}$ & $\mid \begin{array}{l}1.55 \\
5.90\end{array}$ & $\begin{array}{l}1.55 \\
3.58\end{array}$ & $\begin{array}{l}\text { Atropin } \\
\text { p. K. } \\
0.1 \mathrm{mg} .\end{array}$ & $\begin{array}{l}1.35 \\
3.38\end{array}$ \\
\hline 284 & 2.9 & $\begin{array}{l}\mathbf{A} \\
\mathbf{B}\end{array}$ & \begin{tabular}{|l|}
1.16 \\
5.93 \\
\end{tabular} & $"$ & $\begin{array}{l}0.97 \\
8.99 \\
\end{array}$ & \begin{tabular}{|l|}
1.00 \\
5.90 \\
\end{tabular} & $\begin{array}{l}1.16 \\
4.84 \\
\end{array}$ & $\because$ & $\begin{array}{l}.16 \\
3.09 \\
\end{array}$ \\
\hline
\end{tabular}


第 45 圆

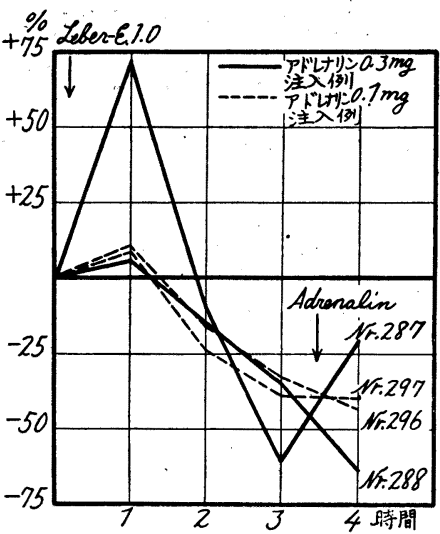

第 46 圖

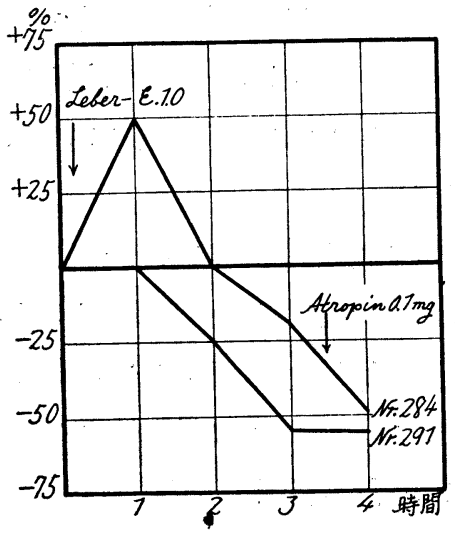

剖ノAceton 體生成抑制作用キ認メタリ。而 シテ Adrenalin 0.1mgr. ニヨリテ起ルベキ Acetonaemie ハ何レモ乳乵ニョリテ抑制セ ラレタルキ知ル。

本項摘要. 肝藏乳剂「プロキロ」1.0 gr. 注 入八Adrenalin $ニ ョ ル$ Acetonaemie 或 程度アデ抑制スル作用アリ。

$$
\begin{aligned}
& \text { 第二項 Atropin }=ヨ ル \text { Acetonae- } \\
& \text { mie 二對スル肝臟孚乵ノ影策 }
\end{aligned}
$$

前項卜同樣ニシテ挀メ肝臟乳乵「プロキロ」 $1.0 \mathrm{gr}$. 注入七ル家鬼二適當ノ時期二Atropin 「プロキロ」0.1mgr. チ注入シ之ニヨリテ當然 起ルベキAcetonaemie 二對シテ学乵が如何二 作用スルカキ見タルニ第 284 及ビ 291 號何レモ 血液 Aceton 體ノ增加テ認メラレズ。

本項摘要. Atropin ノ一定量ニヨリテ 30 分 後上昇スベキ血液 Aceton 體ハ肝臟乳羘「プロ キロ」 $1.0 \mathrm{gr}$. 注入ニヨリテ或程度マデ抑制セラ ル、モノ、如シ。

第三項 肝臟乳劑及ビ Pilocarpin 注

$$
\text { 入ノ場合 }
$$

\begin{tabular}{|c|c|c|c|c|c|c|}
\hline 番諕 & 體重 & \multicolumn{3}{|c|}{ 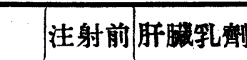 } & $\begin{array}{l}\text { 「ピロカ } \\
\text { ルピン」 }\end{array}$ & 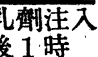 \\
\hline 290 & 2.48 & $\begin{array}{l}\mathbf{A} \\
\mathbf{B}\end{array}$ & $\begin{array}{l}1.35 \\
6.00\end{array}$ & $\begin{array}{c}\text { p. K. } \\
0.05 \mathrm{~g}\end{array}$ & $\begin{array}{c}\text { p. K. } \\
0.4 \mathrm{mg} .\end{array}$ & $\begin{array}{l}1.26 \\
3.38\end{array}$ \\
\hline 292 & 2.32 & $\begin{array}{l}\mathbf{A} \\
\mathbf{B}\end{array}$ & $\begin{array}{l}1.55 \\
3.77\end{array}$ & ," & " & $\begin{array}{l}1.85 \\
6.38\end{array}$ \\
\hline 301 & 2.19 & $\begin{array}{l}\mathbf{A} \\
\mathbf{B}\end{array}$ & $\begin{array}{l}1.35 \\
5.90 \\
\end{array}$ & " & $0 . \ddot{2 m g}$. & $\begin{array}{l}0.87 \\
6.67 \\
\end{array}$ \\
\hline 302 & 2.6 & $\begin{array}{l}\mathbf{A} \\
\mathbf{B}\end{array}$ & $\begin{array}{l}0.97 \\
6.48\end{array}$ & " & " & $\begin{array}{l}0.68 \\
6.96\end{array}$ \\
\hline
\end{tabular}

血液 Aceton 體量二對スル Adrenalin 及ビ

第 25 表
Atropin ノ作用 $コ$ リ推シテ Pilocarpin ハ血液 Aceton體量 キ減少セシムルナラント考フル ハ當然ノコトナリ。然ルニ前章ニ 於ケル實驗ノ結果ハ Pilocarpin 八血液 Aceton 體二對 三何等 影掣チモ與へザルモノ、如シ。

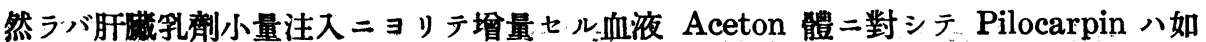
何二作用スベキカ。 
肝藏乳剖注入後 30 分ニシテPilocarpin チ皮下二注入シ更 $=30$ 分テ經テ血液 Aceton

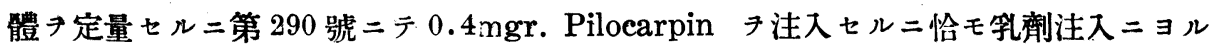
Acetonaemie ヨ抑制セルガ如キモ. 次ノ第 292 號ニ八全然カ、ル事ナク. 又第 301 . 302 號ニテ 0.2mgr. Pilocarpin 注入例ニテハ何レモPilocarpinニヨリテAcetonaemie ノ抑制セラレタリト認メ得ベキモノナシ。

本項摘要. Pilocarpin「プロキロ」0.2-0.4mgr. 皮下注射八何等血液 Aceton 體二

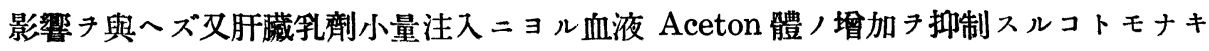
ガ如シ。

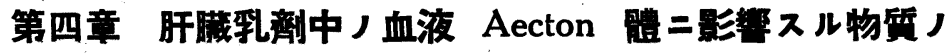 物理化學的性状}

余, 肝臟乳剂中二ハ蛋白質. 脂肪ハ㓜論. 糖類コトニGlykogen 及ビ自家融解ニヨ リテ生ゼル脂肪酸。「ア、ミノ、酸等チ含有セラルベク從ッテ直接血液 Aceton 體二影響 スルモノモ尠シトセズ。而シテ前述,如キ血液 Aceton體二影暗スル物質ガ是等ノ中 ニ屬スルモノナリヤ將又別個ノモノナリヤキ檢セントシテ次ノ如キ實驗き試ミタリ。

$$
\text { 第一項 純酒精 }=ヨ \text { ル試驗 }
$$

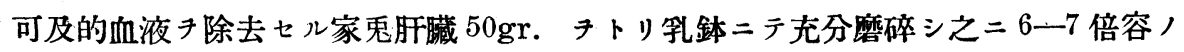

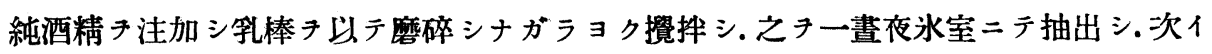
デ滤過シ殘渣ハ再ビ $2-3$ 倍容ノ純酒精キ以テ 3 -4 時間抽出セル後滤過シソノ滤液き 前, 港液卜共 $=50^{\circ} \mathrm{C}$, 乾燥器中二テ酒精及水チ蒸發七シムル時八帶黃色泥狀ノ物質

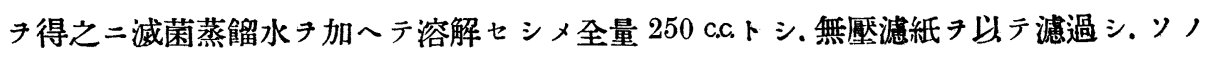
滤液郎于純酒精及ビ水二可溶性 物質 $\mathrm{F}$ 卜 入。又純酒精二不溶部分公同ジク $50^{\circ} \mathrm{C}$ ， 乾燥器ニテ蒸發乾燥シ水キ以テ 250 c.c. トナシ。滤紙キ以テ滤過シソ/滤液テRトス。 然ル時ハ若シ可檢物質ガ全部酒精二可溶ナル時ハFハ恰モ $20 \% /$ 乳乵二相當スベク. 又全然純酒精二不溶ナル時ハ $\mathrm{R}$ ハ恰モソノ $20 \%$ 乳剂二相當スベシ。上ノ如クシテ調 慗セル純酒精二不溶性物質 $(\mathrm{F})$ チ假リ二新鮮臟器, $20 \%$ 乳劑二相當スルモノトシテ 體重「プロキロ」0.05gr. 0.5gr. 及ビ 1.0gr. キ腹腔內二注入シ約 1 時間後二 Butter 酸「プロキロ」0.02 筋内内二注入シテ 10 分ノ後血液 Aceton體き定量セリ。F八 白濁ニシテ蛋白反雔き星セズ。

即于第 298 號二テ八約 $45 \%$. 第 299 號ニテハ $16 \%$ 第 303 號二テハ粕 $27 \%$ 何レモ 著明ノ增加テ認メラル. 而モ Butter 酸 0.02 c.. ニテハ健常家鬼二於テ血液 Aceton 


\begin{tabular}{|c|c|c|c|c|c|c|}
\hline 番號 & 體重 & & 注射前 & 可 檢 物 & 酪酸注入 & $\begin{array}{l}\text { 可檢物 } \\
\text { 注入後 } \\
1 \text { 時間 }\end{array}$ \\
\hline 298 & 2.65 & $\begin{array}{l}\mathbf{A} \\
\mathbf{B}\end{array}$ & $\begin{array}{l}1.35 \\
5.71\end{array}$ & $\begin{array}{c}\mathrm{F} \\
\text { pro Kilo } \\
1.0 \mathrm{~g}\end{array}$ & $0.02 \mathrm{ca}$ & $\begin{array}{l}1.16 \\
8.32\end{array}$ \\
\hline 299 & 2.0 & $\begin{array}{l}\mathrm{A} \\
\mathrm{B}\end{array}$ & $\begin{array}{l}1.54 \\
6.29\end{array}$ & $0.5 \% \mathrm{~g}$ & " & $\begin{array}{l}1.84 \\
7.93\end{array}$ \\
\hline 303 & 2.68 & $\begin{array}{l}\mathrm{A} \\
\mathrm{B}\end{array}$ & $\begin{array}{l}1.35 \\
3.67\end{array}$ & $0.05 \mathrm{~g}$ & " & $\begin{array}{l}1.06 \\
4.74\end{array}$ \\
\hline 235 & 2.73 & $\begin{array}{l}\mathbf{A} \\
\mathbf{B}\end{array}$ & $\begin{array}{l}0.48 \\
\mathbf{3 . 7 7}\end{array}$ & $\begin{array}{c}\mathrm{F}_{1} \\
\text { pro Kilo } \\
0.05 \mathrm{~g}\end{array}$ & $"$ & $\begin{array}{l}0.87 \\
6.38\end{array}$ \\
\hline 242 & 2.83 & $\begin{array}{l}\mathbf{A} \\
\dot{B}\end{array}$ & $\begin{array}{l}1.16 \\
6.26\end{array}$ & , & , & $\begin{array}{l}2.71 \\
8.22\end{array}$ \\
\hline
\end{tabular}

F 純酒精可溶性物質

$F_{i} \quad$ 純酒精「エーテル」可溶性物質
體ノ增加テ來サジルトハ前间。 ニ於テ述べタリ郎チ可檢物質 以 純酒精二可溶性ナリト考へラ ル。

$$
\begin{gathered}
\text { 第二項 Aether キ以 } \\
\text { テスル試驗 }
\end{gathered}
$$

$\mathrm{F}$ 二等量，Aether キ加へ充

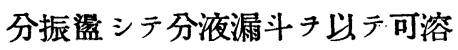
性ノ部分テ分離シ定溫ニテ蒸發 セシメ, 隇菌蒸餾水ニテ約 250 c.c.トシ之キ $F_{1} ト シ$ 腹檫內二體重

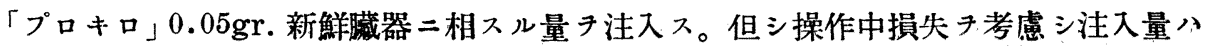
算出セル量ヨリモ常ニ少シク多シ。

郎于第 26 表ノ如ク何レモ著明ノ增加 來ス。

本項摘要. 可檢物質八純酒精二溶解性き有シ又 Aether ニモ溶解スルガ如シ. 恐ラ ク脂肪又ハ脂肪酸ガ大ナル彼割キ演ズルモノナラン。

\begin{tabular}{|c|c|c|c|c|c|c|}
\hline 番號 & 體重 & & 注射前 & $\begin{array}{l}\text { 可 檢 物 } \\
\text { 注 }\end{array}$ & 酪酸注入 & $\begin{array}{l}\text { 可檢物 } \\
\text { 注入後 } \\
1 \text { 時間 }\end{array}$ \\
\hline 230 & 2.82 & $\begin{array}{l}\text { A } \\
\mathbf{B}\end{array}$ & $\begin{array}{l}1.74 \\
5.22\end{array}$ & $\begin{array}{c}\mathrm{R} \\
\text { pro Kilo } \\
0.05 \mathrm{~g}\end{array}$ & $\begin{array}{c}\text { p. K. } \\
0.02 \text { c.c. }\end{array}$ & $\begin{array}{l}1.84 \\
6.48\end{array}$ \\
\hline 239 & 2.78 & $\begin{array}{l}\text { A } \\
\text { B }\end{array}$ & $\begin{array}{l}1.55 \\
6.77\end{array}$ & ," & " & $\begin{array}{l}1.45 \\
8.03\end{array}$ \\
\hline 257 & 2.47 & $\begin{array}{l}\text { A } \\
\text { B }\end{array}$ & $\begin{array}{l}1.64 \\
5.61\end{array}$ & $\begin{array}{c}\mathrm{R}_{1} \\
\text { pro Kilo } \\
0.05 \mathrm{~g}\end{array}$ & " & $\begin{array}{l}0.87 \\
6.38\end{array}$ \\
\hline 259 & 2.48 & $\begin{array}{l}\text { A } \\
\text { B }\end{array}$ & $\begin{array}{l}1.93 \\
3.19\end{array}$ & $"$ & ", & $\begin{array}{l}1.26 \\
3.28\end{array}$ \\
\hline 268 & 2.85 & $\begin{array}{l}\mathrm{A} \\
\mathrm{B}\end{array}$ & $\begin{array}{l}1.64 \\
6.58\end{array}$ & ", & " & $\begin{array}{l}1.45 \\
8.41\end{array}$ \\
\hline 269 & 2.74 & $\begin{array}{l}\text { A } \\
\text { B }\end{array}$ & $\begin{array}{l}1.16 \\
3.48\end{array}$ & $\begin{array}{c}\mathrm{R}_{2} \\
0.05 \mathrm{~g}\end{array}$ & $"$ & $\begin{array}{l}1.06 \\
5.03\end{array}$ \\
\hline 270 & 2.77 & $\begin{array}{l}\text { A } \\
\text { B }\end{array}$ & $\begin{array}{l}1.83 \\
4.25\end{array}$ & ", & ", & \begin{tabular}{l|}
1.45 \\
7.64
\end{tabular} \\
\hline
\end{tabular}

第三項 純酒精ニ不溶成分キ以テスル試驗

$\mathrm{R}$ 純酒精不溶性物質

$\mathrm{R}_{\mathbf{i}} \mathrm{R}$ /牛䭂和硫酸安門ニテ沈澱セザル物資

$R_{2} \cdot R_{1} \nu$ 飽和硣酸安門二广沈测セザル物質
純酒精二不溶二シテ水二溶解 スル物質 $\mathrm{R}$ 八白色乳濁ノ液體二 ジテ pH 6.6 Sulfo. 陽性. Heller 陽性 Xauthoprotein 陰性 Biuret 中等度陽性. Ninhydrin 强 陽性ノ液體ナリ。之キ新鮮藏器 $20 \%$ モノト假定シ體重「プロ キロ」0.05gr. ノ割二腹腔內二 注入シ. 約 1 時閔後 $=$ Butter 酸「プロキロ」0.02 c.c. キ筋肉內 二注入 シ テ 10 分後採血定量七 リ。(以下可檢物質，作用檢出二 八同樣ノ力法き以テセり。)

ソノ結果テ見ルニ何レモ注入 
後 10 分ニシテ著明ノAceton 體ノ增加テ來シ. Butter 酸ヨリノAceton 體生成 促進セルガ如シ。

本項摘要. 肝藏乳劑中ノ血液 Aceton 二作用スル物質ハ一部分酒精及ビ Aether ニ移行スル如キモ. 一部分八純酒精二不溶ナルガ如シ。

第四項 硫酸安門キ以テスル實驗

（A）牛飽和ノ狀態二於ケル實驗

純酒精不溶部分 $\mathrm{R}$ ノ一定量二飽硫酸安門水溶液等容量加へ暫時定溫二放置シテ析

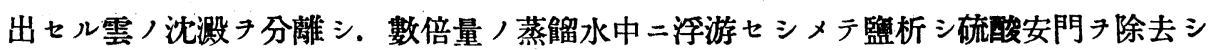
タル後 $50^{\circ} \mathrm{C}$ ノ乾燥器中二テ元ノ量マデ、濃縮シ之キ $R_{1}$ トシ體重「プロキロ」0.05gr.， 割二腹腔內二注入シテ檢七リ。 $\mathrm{R}_{1}$ 八 pH.6.2, Sulfo. 陰性. Biuret 陽性. Ninhydrin 强陽性透明ノ液體ナリ。ソノ影響き觀察スルニ何レモ $\beta$-Oxybutter 酸ノ著明ノ增加 キ來シ～Rト殆ント變ラズ。郎チ肝藏細胞成分中ノ血液 Aceton 體二影響スル物質八 硫酸安門，牛飽和ノ狀態二テハ沈澱セザルガ如シ。

\section{（B）飽和ノ狀態ニ於ケル賽驗}

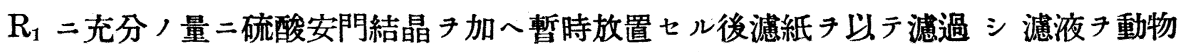

\begin{tabular}{|c|c|c|c|c|c|c|}
\hline 番號 & 體重 & & 注射前 & $\begin{array}{l}\text { 可檢物 } \\
\text { 注入 }\end{array}$ & 酪酸注入 & $\begin{array}{l}\text { 可檢物 } \\
\text { 注入後 } \\
1 \text { 時間 }\end{array}$ \\
\hline 251 & 2.65 & $\begin{array}{l}\mathrm{A} \\
\mathrm{B}\end{array}$ & $\begin{array}{l}1.83 \\
8.12\end{array}$ & $\begin{array}{c}\mathrm{Rt} \\
0.05 \mathrm{~g}\end{array}$ & $\begin{array}{l}\text { p. K. } \\
0.02 \text { 犝 }\end{array}$ & $\begin{array}{l}1.93 \\
8.71\end{array}$ \\
\hline 252 & 2.8 & $\bar{A}$ & & ", & $"$ & $\begin{array}{l}1.55 \\
6.29 \\
\end{array}$ \\
\hline 274 & 2.76 & $\begin{array}{l}\mathrm{A} \\
\mathrm{B}\end{array}$ & $\begin{array}{l}1.45 \\
4.06 \\
\end{array}$ & $\begin{array}{c}\mathrm{Rk} \\
0.05 \mathrm{~g}\end{array}$ & $"$ & $\begin{array}{l}1.26 \\
5.51 \\
\end{array}$ \\
\hline 275 & 2.16 & $\begin{array}{l}\mathrm{A} \\
\mathrm{B}\end{array}$ & $\begin{array}{l}.65 \\
5.71\end{array}$ & ", & " & $\begin{array}{l}1.65 \\
7.25 \\
\end{array}$ \\
\hline 276 & .78 & $\begin{array}{l}\mathbf{A} \\
\mathbf{B}\end{array}$ & $\begin{array}{l}1.45 \\
6.77 \\
\end{array}$ & $\begin{array}{c}\mathrm{R}_{\mathrm{D}} \\
0.05 \mathrm{~g} \\
\end{array}$ & ", & $\begin{array}{l}1.45 \\
3.58 \\
\end{array}$ \\
\hline 278 & 2.4 & $\begin{array}{l}\mathbf{A} \\
\mathbf{B}\end{array}$ & $\begin{array}{l}1.64 \\
6.87 \\
\end{array}$ & ", & ", & $\begin{array}{l}1.52 \\
5.80 \\
\end{array}$ \\
\hline 278 & 2.4 & $\begin{array}{l}\mathbf{A} \\
\mathbf{B}\end{array}$ & $\begin{array}{l}1.54 \\
6.87 \\
\end{array}$ & $\begin{array}{c}\mathrm{Rd} \\
0.05 \mathrm{~g} \\
\end{array}$ & " & \begin{tabular}{|l|}
1.93 \\
7.64 \\
\end{tabular} \\
\hline 79 & 17 & 1 & $\begin{array}{l}1.93 \\
6.87\end{array}$ & $\begin{array}{c}R_{3} \\
0.05 \mathrm{~g} \\
\end{array}$ & $"$ & $\begin{array}{r}1.64 \\
4.84 \\
\end{array}$ \\
\hline 2.80 & 2.57 & $\begin{array}{l}\mathbf{A} \\
\mathbf{B}\end{array}$ & $\begin{array}{l}0.87 \\
7.60 \\
\end{array}$ & , & $"$ & $\begin{array}{l}0.67 \\
5.32 \\
\end{array}$ \\
\hline 2.46 & 2.85 & $\begin{array}{l}\mathrm{A} \\
\mathrm{B}\end{array}$ & $\begin{array}{l}0.87 \\
7.74 \\
\end{array}$ & $\begin{array}{c}\mathrm{H} \\
0.05 \mathrm{~g} \\
\end{array}$ & $"$ & $\begin{array}{l}1.06 \\
8.90 \\
\end{array}$ \\
\hline
\end{tabular}
膜ニテ $\mathrm{R}_{1}$ ノ如ク監析シ. 濃樎 シテ得タル液體 $\mathrm{R}_{2}$ トス。 $\mathrm{pH} 6.0$, Biuret 弱陽性. Ninhydrin 中等度陽性透明, 液體 ナリ。之キ例ノ如キ「プロキロ」 $0.05 \mathrm{gr}$. 相當量家鬼, 腹腔内二 注入セリ。ソノ結果八第 27 表ノ 如ク血液 Aceton體ノ增加來 セリ。郎于肝藏細胞成分中ノ該 物質一硫酸安門，飽和ノ狀態二 テモ沈澱セズ。

\section{第五項 吸著試驗}

純酒精不溶物質 $\mathrm{R}$ 歐炭未及 ビ Kaorin キ以テ吸著七シメ之 テ滤紙テ以テ滤過シテ得タル無 $\mathrm{R}_{\mathrm{t}}$ 獸宸末ショり吸著七ラレザル物算 $\mathrm{Rd}$ 透 析液 $\mathbf{R}_{\mathrm{D}}$ 被透析液 色透明ノ液き夫々 $\mathbf{R}_{\mathrm{t}}$ 及ビ $\mathbf{R}_{\mathrm{k}}$ 
トス。何レモ pH 5.8-6.0. Sulfo 陰性. Biuret 陰性. Ninhydrin 弱陽性ナリ。之 キ「プロキロ」0.05gr. 相當量キ腹腔內二注入セリ。

郎于第 251. 274 及ビ 275 號二於ケルガ如ク血液 Aceton 體コトニ $\beta$-Oxybutter 酸ノ生成み促進セルチ認ム。

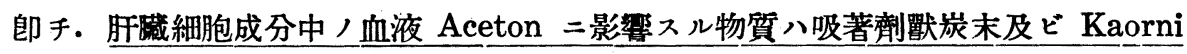
ニョリテ吸著セラレズ。

\section{第六項 透析試驗}

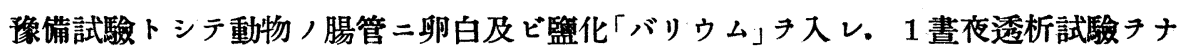
シ透析液中蛋白反應き呈セズシテ監化「バリウム」ノ反應ノミ゙認メタルモノキ透析膜 トシテ之ニ $\mathrm{R}$ ノ一定量キ入レ.ソノ數倍容ノ隇菌蒸餾水中二浮游セシメ水室二テ 2 書

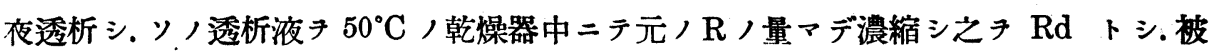
透析液き。 $R_{\mathrm{D}}$ トス之チ例ノ如ク.夫々「プロキロ」0.05gr. 相當量宛腹腔内二注入シ 血液 Aceton體ノ增減キ檢セリ。ソノ結果ヨ見ルニ第 28 表. 第 276 及ビ 278 號ノ如ク 被透析液ハ血液 Aceton 體增加スルコトナク. 透析液八Aceton 體ノ生成き促進

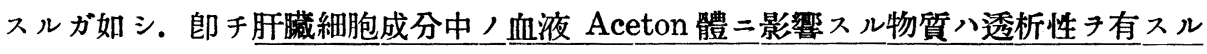
モノ、如ク. 而シテソノ透析液ハ Biuret 陰性. Ninhydrin 弱陽性ナリ。

第七項 灰化試驗

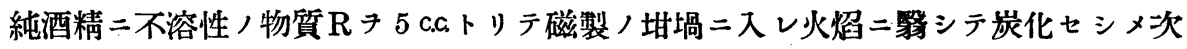
イデ灰化セシメタル物質ョ 5 c.c. ノ水二溶解シ之ョ $\mathrm{R}_{3}$ トス。例ノ如ク「プロキロ」0.05 gr. 相當量き腹腔內二注入シテ血液 Aceton 體ニ及ボス影䍹き見タルニ第 28 表. 第

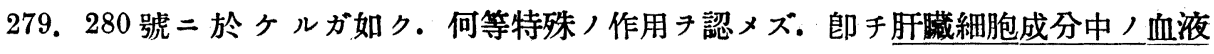
Aceton 時二影響スル物質ハ灰化スルコトニヨリテソノ作用テ失フモノ、如シ。

\section{第八項 加熱試驗}

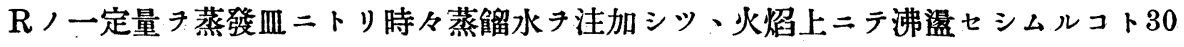
分ノ後之キ元ノ量二補正シ例ノ如ク體重「プロキロ」0.05gr. 相當量キ家兔ノ腹腔內二 注入シ次イデ Butter 酸!プロキロ」0.02 c.c.筇肉注入シテ血液 Aceton.體二及ボ ス影響キ見ルニ. 第 28 表第 246 號ノ如ク・ $\beta$-Oxybutter 酸ノ增加き來セリ. 郎于肝藏

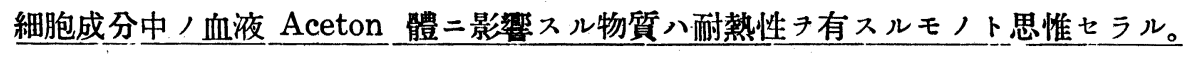

\section{第五章 總括及七考按}

以上ノ實驗き總括スレバ次ノ如シ。 
1. Adrenalin「プロキロ」0.1一0.3mgr.尹皮下二注入スル時八 30 分後血液 Aceton 體コトニ $\beta$-Oxybutter 酸ノ增加キ來ス。

2. Atropin「ブロキロ」0:1mgr. /注入ニヨリテ同ジゥ30 分後二血液中， $\beta-O x y-$ butter 酸フ增加ス。

3. Pilocarpin「プロキロ」0.2-0.4mgr. 注入八何等血液 Aceton體ノ變化キ來サ ズ。

4. 肝藏乳劑大量 (「プロキロ」 $1.0 \mathrm{gr}$. $)$ 注入ニヨリテオコル血液 Aceton 體ノ減少ハ Adrenalin (0.1-0.8mgr.) 又心 Atropin (0.1mgr.) ニョリテ左右セラレズ。

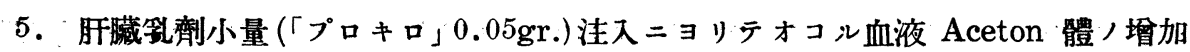
ハPilocarpin (0.2-0.4mgr:) ニヨリテ抑制セラレズ。

6. 肝贜細胞成分中，血液Aceton 體二影響スル物質 1 部分八純酒精及ビ Aethe 二溶解スルモ 1 部分八純酒精二移行セズ。

7. 純酒精二移行セザル該物質八硫酸安門ノ牛飽和ニテ沈澱セズ, 、飽和ニヨリテ モ沈澱セズ。

8. 又獸炭末及ビ Kaorin ニョリテモ吸著セラレズ。

9. 透析性タ有シ，耐熱性多有シヌ

10. 又灰化スル時ハソノ效力キ失フ。

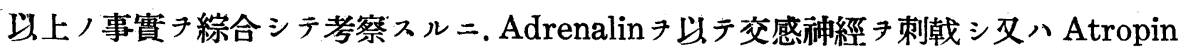
尹以テ副交感神經尹磨痹七 シメテ比較的 Sympatikotonie，狀態ニスル時ハ血液

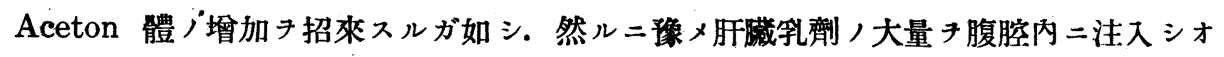
ク時ハコノ作用キ消失七シメ血液 Aceton 體ノ增加キ來サズ. そ畢竟スルニ. 肝臟乳 劑中ノアル物質ガ直接肝臟實質細胞二作用シテ・ソノAceton 體生成機能チ動メ低下 スルチ以テ後來ノ是等植物神經毒、Acetonaemie キ惹起スベキ刺戟テ作ルニ至ラザ ルモノナラン。一方 Pilocarin ハ「プロキロ」0.2一0.4mgr，注入ニヨリテハ。肝㵴 乳劑小量注入 $ニ ヨ$ Acetonaemie チ抑制シ又增强モスルコトナシ。以之觀之: 旰藏細 褜成分中ノ血液 Aceton 體二對スル影譻八恐ラク神經テ介スルモノニハ韭ズシテ直接 肝藏細胞二作用シテソ，Aceton 體生成機能亢進若シク八抑制スルモノナラン。

又血液 Aceton 體增加性物質, 物理化學的性狀 $リ$ 考察スルニ.一部分八純酒精及 ビAether二溶解スルキ以テ脂肪及ビ脂肪酸ノ類きモ考へラルベク.勿論是等ハAceton 體ノ母體ナルチ以テ Aceton體ノ增加テ來スハ何等異トスルニ足ラズ。然ルニ一部分 八純酒精二不溶性ナリ. 郎チ脂肪類以外, 物質モ亦 Aceton 體生成二與り居ルカ如シ. 


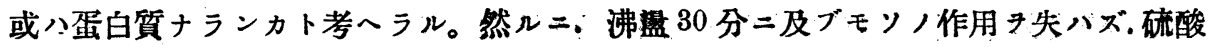
安門ノ牛飽ニヨリテモ又飽和ニヨリテモ沈測七ズ. Sulfosalicyl 酸反鷹. Heller 氏反 應. Xanthoprotein 反應. Biuret 反應等何レモ陰性トナリ唯 Ninhydrin 反應ノミ弱 陽性ナルニ拘ラズ乔該作用き認ムルハ蛋白質トモ考へ難ク又獸炭末 Kaorin 二モ吸著 セラレズヌ透析性习.有スル等. 或八無機物ナ.ランカトモ考へラル、モ灰化スレバソ,

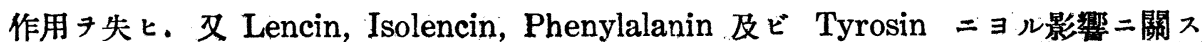
ル實驗ヨリ推察スレバ是等「アミノ」酸ニモ非ルベシ。カ、ル脂肪ニモ非ズ．蛋白質乃 至「アミノ」酸二モ非ズ． 又無㙨物ニモ非ザル一種/物質が極メテ少量ニテ肝細胞ヨ刺 戟シテ血液 Aceton體增加シ大量ナル時八始入刺戟性二作用スルモ後刺戟ノ增强ス ルニ從ヒ却ヘッテ毒性二作用シテ血液 Aceton體ノ減少キ來スモノナラン。而シテ該 物質八恰モ宮川敎授ノAutohormon ナルベク・ソフ肝臟二對スル作用八藏器特異性 テ有シ・神經ョ介スルコトナクシテ直接肝臟細胞二作用シ. 神經性調節. Hormon 性 調節ト共二肝要ナル調篇作用キ營ムモノナルベク血液 Aceton 體モ亦同樣ニシテ調節 セラル、モノナラン。

\section{第六章 結 蛹}

本實驗成績ハ次ノ如ク結論スルコトキ得。

1. Adrenalin 體重「プロキロ」0.1一0.3mgr. ヨ皮下二注入スル時ハ 30 分ニシテ 血液 Aceton 體增加 ス。

2. Atropin 體重「プロキロ」0.1mgr. 皮下二注入スル時八同ジク 30 分ニシテ血液 Aceton 體ノ增加 來ス。

3. Pilocarpin「プロキロ」0.2-0.4mgr. 皮下二注入スルモ血液 Aceton 體量八 特殊ノ變化キ蒙ラズ。

4. 像メ肝臟乳剂大量ヨ腹腔內二注入シォク時ハ後二適當量, Adrenalin 若シク 八Atropin キ注入スルモ血液 Aceton 體量八增加セズ。郎チ大量ノ肝铜乳劑ニヨリ テ抑制セラレタル肝臟, Aceton 體生成機能八是等植物性神經毒ノ前記ノ量ノ注入二 ヨリテ何等ノ影響き蒙ラズ。

5. 肝臟乳剂小量注入 $ニ ヨ ル$ 血液 Aceton 體ノ增加ハ. Pilocarpin「プロキロ」0 4 mgr. 注入ニヨリテ抑制セラレズ。

6. 肝矌細胞成分中血液 Aceton 體量二影袜スル物質ハ一部分純酒精及ビ Aether 二溶解シ一部分八純酒精二溶解セズ。又 
7. 硫酸安門ノ牛飽和及ビ飽和ノ狀態ニ於テ沈測セズ。

8. 耐熱性き有スルモ灰化スレバソフ作用す失う。

9. 獸㞸末及ビ Kaorin ニ゙ョリ吸著セラレズ。

10. 透析性子有入。

稿キ終ルニ臨そ長與所長二敬意キ表シ。始終御懇篤ナル御指導。御䩿撻キ睗リタル

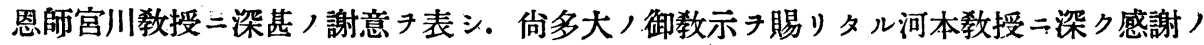
意き表ス。

\section{圭要文 啹}

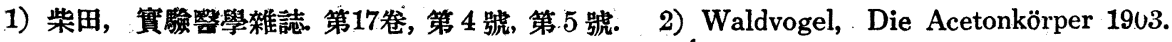
3)溝口, 日本內分泌學會雜誌. 第 4 卷, 第 2 號. 4) P. Clerc, Zs. f. kl. Med. Bd. 118, 5-6, H. 5) S. Seelig, Zs. f. ges. exp. Med. Bd. 79, 3-4. H. 1931 . 6) F. Stroebe, Zs. kl. Med. Bd. 118, 5-6, H. 7) Meyer u. Gottlieb, Experimentelle Pharmakologie 6 te Aufl. 8). 柿內，生化學提要. 1927。9）新免，賽驗醫學雜誌. 第 13 卷, 第 5 號. 10）奥野，筫騟 醫學雜誌. 第 11 卷, 第 10 號, 第 11 卷, 第 7 號. 11) 佐藤, 賽驗醫學雜誌. 第 15 卷. 第 9 號. 12）宮川, 筫驗㗨學雜誌, 第 7 卷, 第 1 號. 13）高畑, 久米, 生物化學分析. 14）Fischler, Physiolog. u. Pathologie der Leber 1923. 15) 林, 䒚理學. 昭和二年. 16) Joseph Blöch, Zs. kl. Med. 117 Bd. 1-2, H. 17) Wilhelm milbrat, Zs. f. ges. exp. Med. Bd. 81, 1-2, H. 18) H. Zondeck, Die Kraukh. d. Endokrinen Diủsen 2te Aufl. 